\title{
PKM INOVASI PEMBELAJARAN MATEMATIKA SD/MI MELALUI PERMAINAN ULAR TANGGA
}

\author{
Seruni $1^{1 *}$, Fauzi Mulyatna ${ }^{2^{*}}$, Arfatin Nurrahmah ${ }^{3}$ \\ ${ }^{1}$ Program Studi Pendidikan Matematika, Universitas Indraprasta PGRI Jakarta \\ ${ }^{2}$ Program Studi Pendidikan Matematika, Universitas Indraprasta PGRI Jakarta \\ ${ }^{3}$ Program Studi Pendidikan Matematika, Universitas Indraprasta PGRI Jakarta \\ Corresponding author: \\ E-mail: fauzi.mulyatna@unindra.ac.id
}

Diterima 4 September 2019, Disetujui 16 September 2019

\begin{abstract}
ABSTRAK
Kegiatan Pengabdian kepada Masyarakat (PkM) ini bertujuan mengatasi masalah yang dialami oleh guru di lingkungan Kelompok Kerja Madrasah Ibtidiyah Kecamatan Jagakarsa, Jakarta Selatan, yaitu kesulitan guru dalam menumbuhkan minat belajar siswa untuk mempelajari matematika karena kurang menguasai metode, model, pendekatan pembelajaran yang menyenangkan dan inovatif. Salah satunya dengan permainan ular tangga sebagai inovasi pembelajaran matematika di tingkat Sekolah Dasar. Ular tangga adalah salah satu permainan tradisional dimana papan permainan ular tangga terdiri dari kotakkotak kecil yang sudah diberi nomor dan beberapa gambar seperti tangga dan ular, yang dapat menghubungkan kotak satu ke kotak yang lainnya. Permainan ular tangga dimodifikasi sedemikian rupa peraturannya serta bidang permainannya sebagai inovasi pendekatan pembelajaran matematika yang menyenangkan. Kegiatan pengabdian ini diikuti oleh 48 orang perwakilan guru MI se-Kecamatan Jagakarsa. Metode pelaksanaan kegiatan ini dengan melakukan penjelasan mengenai apa manfaat pendekatan permainan ular tangga serta bagaimana cara pemanfaatannya dan hubungannya dengan matematika, pengenalan permainan tradisional itu sendiri kemudian dilanjutkan pada implementasi permainan ular tangga, hingga membuat soal-soal matematika yang berkaitan dengan materi matematika menggunakan pendekatan permainan ular tangga. Luaran yang didapat dari kegiatan pengabdian ini, yaitu guru MI se-Jagakarsa dapat menerapkan pengetahuan yang didapat dari kegiatan pengabdian ini kepada siswa.
\end{abstract}

Kata kunci: pembelajaran matematika, permainan, ular tangga

\begin{abstract}
Activity Community Service aims to address problems experienced by teachers in the Working Group Madrasah Ibtidiyah Jagakarsa, South Jakarta, namely the difficulty of teachers in fostering student interest to learn math because lack of control methods, models, learning approach that is fun and innovative. One of them with a game of snakes and ladders as an innovative learning of mathematics at the elementary level.Snakes and ladders is one of the traditional game of snakes and ladders board game which consists of small boxes that have been given a number and a few images such as ladders and snakes, which can connect one box to another box. Snakes and ladders game rules modified in such a way as well as areas of the game as an innovative approach to learning math fun. This service activities attended by 48 representatives of teachers MI se Jagakarsa. The method of this activity by doingan explanation of what the benefits of snakes and ladders to approach the game and how its use and its relationship with math, introduction to traditional games itself and then proceed to the implementation of the game of snakes and ladders, to create math problems relating to the material using a mathematical approach to the game of snakes and ladders. Outcomes obtained from these service activities, namely MI se-Jagakarsa teacher can apply the knowledge gained from this service activities to the students.
\end{abstract}

Keywords: mathematics education, games, snakes and ladders

\section{PENDAHULUAN}

Matematika memiliki peran penting dalam berbagai bidang ilmu, karena ilmu matematika diterapkan pada kehidupan seharihari. Sedemikian pentingnya hingga matematika perlu dibekali kepada siswa mulai dari jenjang sekolah dasar agar memiliki kemampuan berpikir logis, sistematis, kritis, serta mampu bekerja sama dalam lingkungan. Kemampuan-kemampuan tersebut dapat 
dikembangkan apabila strategi pembelajaran yang diberikan tepat. Namun, pentingnya matematika dalam bidang pendidikan, tidak sejalan dengan pandangan siswa terhadap matematika. Sebagian besar siswa masih menganggap matematika merupakan mata pelajaran yang sulit dan tidak menyenangkan untuk dipelajari, sehingga muncul istilah "mathematics is monster". Anggapan yang melekat pada siswa tersebut berdampak negatif pada proses dan hasil pembelajaran siswa.

Berdasarkan hasil pengamatan dan informasi yang diperoleh, pembelajaran matematika di kelas masih menggunakan metode konvensional. Guru berperan sebagai pusat pembelajaran sehingga siswa kurang terlibat secara aktif selama pembelajaran. Kondisi ini menjadikan pembelajaran matematika kurang menarik di mata siswa dan akibatnya siswa kurang bersemangat selama proses pembelajaran.

Merancang proses pembelajaran melalui Rencana Pelaksanaan Pembelajaran (RPP) di kelas merupakan hal yang penting. RPP ini terkadang hanya sebatas pemenuhan administratif saja. Pembelajaran dengan persiapan RPP yang baik, menjadikan proses pembelajaran di kelas menjadi teratur terarah dan mudah dalam melakukan evaluasi untuk proses selanjutnya. Berdasarkan temuan dalam penelitian Mulyatna (2017), bahkan guru sendiri terkadang belum mengerti betul arti pentingnya RPP.

Dalam pengabdian masyarakat Mulyatna, Indrawati, \& Hartati (2018), sebagai kelanjutan dari hasil penelitian, telah dilakukan pelatihan perancangan RPP yang baik. Penyusunan RPP yang baik kemudian diikuti dengan penerapannya dalam pembelajaran, dapat mengahasilkan proses belajar-mengajar yang terstruktur, terarah dan mempunyai tujuan yang jelas. Dalam RPP memuat deesain pembelajaran yang akan dilaksanakan. Melalui pengabdian masyarakat ini, meneruskan perbaikan proses pembelajaran yang didahului dengan pembuatan RPP kemudian dalam desain pembelajaran diikuti dengan pendekatan permainan tradisional.

Pemilihan permainan tradisional sebagai pendekatannya, karena atas dasar dari hasil wawancara yang dilakukan kepada guru dan siswa yang berada di lingkungan Kelompok Kerja Madrasah Ibtidaiyah Jakarta Selatan, ditemukan bahwa sebagian besar guru kelas yang mengajar matematika merupakan guru yang mempunyai latar belakang selain pendidikan matematika. Hal ini menyebabkan guru kurang memahami konsep dan kurang memahami bagaimana cara mengaitkan materi matematika dengan permasalahan yang ada di kehidupan sehari-hari. Selain itu, guru mengungkapkan bahwa kesulitan selama ini dalam mengajar matematika adalah kurangnya minat belajar siswa karena sudah menganggap matematika sulit. Terutama saat mempelajari konsep pecahan, perkalian dan pembagian. Hal yang sama pun dirasakan sebagian siswa, kesulitan mengingat materi mengenai konsep yang agak rumit. Ketika menemukan kesulitan, siswa merasa tidak semangat untuk belajar matematika.

Permasalahan-permasalah ini juga terjadi pada guru-guru di Kelompok Kerja Madrasah Ibtidaiyah (KKMI) Kecamatan Jagakarsa, Jakarta Selatan, sebagai mitra kegiatan pengabdian masyarakat. Sebagian besar guru kelas yang mengajar, bukan merupakan guru yang berlatar belakang pendidikan matematika. Guru kurang memahami konsep dan kurang memahami bagaimana cara mengaitkan materi matematika dengan permasalahan yang ada di kehidupan sehari-hari. Guru lebih sering menggunakan model pembelajaran konvensional yang berlangsung satu arah, yaitu guru menjelaskan dan siswa mendengarkan, tanpa memperhatikan apakah siswa mengerti atau tidak. Hal ini menyebabkan siswa tidak semangat dan kurang menyenangi matematika, ditambah lagi materi yang diajarkan dianggap sulit oleh siswa.

Untuk mengatasi kelemahan tersebut dan memotivasi siswa agar menyenangi matematika, maka diperlukan suatu tindakan dalam pembelajaran yang mampu meningkatkan motivasi belajar siswa yaitu dengan memberikan suatu pendekatan pembelajaran yang baru. Salah satunya seperti pendekatan permainan yang fungsinya untuk memancing siswa dalam belajar, artinya bermain sambil belajar. Cara permainan yang melibatkan dua orang atau lebih dapat menumbuhkan sikap sosial pada diri anak. Pembelajaran matematika melalui permainan dapat digunakan oleh guru dalam melaksanakan tugasnya untuk menyampaikan materi dan membantu pembentukan sikap siswa. Kegiatan pengabdian ini diharapkan mampu menumbuhkan sikap positif kepada siswa dalam pembelajaran dan dapat mengubah cara pandang siswa terhadap mata pelajaran matematika. Kemampuan guru untuk menguasai konsep-konsep matematika dengan baik sehingga mampu menyajikan materi dengan menarik, juga diperlukan agar anggapan siswa yang menganggap matematika merupakan satu momok sebagai ilmu yang sulit dan kurang menarik untuk dipelajari dapat termotivasi dalam mempelajari matematika. Menurut Turmudi (2008: 80) 
merubah sikap siswa menjadi positif terhadap matematika membutuhkan strategi pembelajaran matematika yang menarik bagi siswa, memotivasi mereka belajar, memberikan rasa aman untuk belajar, dan menyenangkan bagi mereka.

\section{METODE PELAKSANAAN}

Metode pelaksanaan kegiatan ini dibagi menjadi beberapa tahapan, antara lain: 1) Tahap Pendahuluan. Pada tahap ini dilakukan untuk mendapatkan informasi mengenai pembelajaran matematika yang biasa dilakukan, serta permasalahan-permasalahan mengenai pembelajaran matematika di sekolah. 2) Tahap sosialisasi dan audiensi. Sosialisasi mengenai inovasi pembelajaran matematika SD yang menyenangkan melalui pendekatan permainan ular tangga dilakukan dengan cara mengumpulkan perwakilan guru yang mengajar matematika di Kelompok Kerja Madrasah Ibtidaiyah Kecamatan Jagakarsa, Jakarta Selatan. Para peserta diberi penjelasan mengenai bagaimana menjadi guru yang menyenangkan bagi siswa serta apa manfaat pendekatan permainan ular tangga serta bagaimana cara pemanfaatannya dan hubungannya dengan matematika. 3) Tahap Pelaksanaan. Pada tahap ini dilakukan simulasi kepada guru mengenai penerapan permainan ular tangga sebagai inovasi pembelajaran matematika. Simulasi juga dilakukan dalam perancangan pembelajaran dengan permainan tradisional. Tim pengadian mempraktekkan langsung serta memberikan contoh yang diikuti oleh para guru SD/MI setahap demi setahap. Setelah itu, guru di lingkungan Kelompok Kerja Madrasah Ibtidaiyah Kecamatan Jagakarsa, Jakarta Selatan, akan dibimbing untuk mengembangkan sendiri rancangan pembelajaran menggunakan pendekatan permainan tradisional hingga membuat soalsoal yang berkaitan dengan materi matematika menggunakan pendekatan permainan tradisional. Pelaksanaan kegiatan dilakukan selama dua hari pada bulan Juli dan diikuti oleh 48 orang perwakilan SD/MI yang tergabung dalam Kelompok Kerja Guru MI se Kecamatan Jagakarsa, Jakarta Selatan. Tempat kegiatan dipilih berdasarkan kemudahan akses untuk mencapai lokasi, sehingga disepakati tempat kegiatan di MI Wijaya Kusuma, yang terletak di Jalan Raya Depok No.16, Lenteng Agung, Kecamatan Jagakarsa, Jakarta Selatan

\section{HASIL DAN PEMBAHASAN}

\begin{tabular}{llr}
\multicolumn{2}{c}{ Pelaksaanaan kegiatan Pengabdian } \\
kepada Masyarakat & (PkM) & Inovasi \\
pembelajaran matematika & SD/MI & melalui
\end{tabular}

permainan ular tangga yang dilakukan di $\mathrm{Ml}$ Wijaya Kusuma dihadiri oleh 48 perwakilan guru dari Kelompok Kerja Guru Madrasah Ibtidaiyah se-Kecamatan Jagakarsa, Jakarta Selatan. Berdasarkan hasil survey yang dilakukan pada tahap pendahuluan, disepakati mengenai tema pelatihan yang akan diberikan, tempat pelaksanaan serta peserta yang akan diundang mengikuti kegiatan. Tema yang dipilih mengenai inovasi pembelajaran matematika yang menyenangkan melalui pendekatan permainan ular tangga. Permainan ular tangga dipilih karena dalam permainan ini dapat dikaitkan dengan bermacam-macam materi pelajaran matematika sehingga guru dapat mengkreasikan sendiri permainan ini. Guru dibantu untuk dapat merancang pembelajaran yang lebih menyenangkan bagi siswa.

Pelaksanaan kegiatan dilakukan selama dua hari, di mana hari pertama akan dilakukan tahap sosialisai dan audiensi, hari kedua akan dilakukan tahap simulasi atau demonstrasi, dan tahap ketiga adalah evaluasi. Pada hari pertama, tim menyampaikan materi mengenai inovasi pembelajaran melalui pendekatan permainan. Metode permainan adalah metode pengajaran matematika melalui permainan matematika. Permainan matematika adalah suatu kegiatan yang menyenangkan (mengembirakan) yang dapat menunjang tercapainya tujuan instruksioanal dalam pengajaran matematika baik, aspek kognitif, afektif maupun psikomotor. Tim juga menjelaskan tentang alur, tata cara menggunakan media yang disediakan dan konsep matematika apa saja yang sesuai dengan permainan tersebut. Kemudian disampaikan juga mengenai kelebihan dan kekurangan dari permainan tradisional. Adapun kelebihan metode permainan, antara lain: a) Keterampilan siswa dalam bidang matematika seperti menghitung dan menganalisis semakin meningkat, b) Konsep-konsep matematika akan lebih mantap untuk dipahami, c) Kemampuan manemukan dan memecahkan masalah meningkat, d) Siswa lebih tertarik dan termotivasi untuk belajar matematika. Sedangkan kelemahan dari metode permainan, antara lain: a) Tidak semua topik dapat disajikan dengan metode permainan makin tinggi tingkatnya makin sukar disajikan, disamping itu permainan pun harus kita buat sendiri (tidak dalam bentuk siap pakai), b) Memakan banyak waktu, c) Permainan mungkin akan mengganggu ketenangan kelaskelas disekitarnya. Oleh karena itu, dalam menyampaikan materi dengan pendekatan permainan tradisional diperlukan perancanaan yang matang dan sistematis oleh guru, agar 
tujuan pembelajaran dapat tercapai dengan baik.

Di hari selajutnya, kegiatan dimulai dengan penyampaian simulasi permainan tradisional oleh tim. Pada kegiatan ini, guruguru akan mensimulasikan permainan yang sudah disiapkan oleh tim, yaitu permainan ular tangga. Sebelumnya seluruh guru dibagi menjadi delapan kelompok, di mana masingmasing kelompok terdiri dari enam orang. Tiap kelompok akan mensimulasikan permainan ular tangga sesuai dengan arahan tim abdimas. Pertama-tama tim abdimas menjelaskan aturan permainan serta memberikan penjelasan sesuai dengan konsep matematika yang ada dalam permainan, dan kemudian seluruh kelompok melakukan permainan sesuai yang dicontohkan. Satu orang di tiap kelompok bertindak sebagai guru yang akan menjadi wasit dalam permainan, dan sisanya dianggap sebagai peserta didik. Seluruh guru terlihat antusias dan semangat ketika mensimulasikan permainan tradisional tersebut. Peserta diberikan kesempatan untuk memberikan tanggapan atas kegiatan yang sudah dilakukan selama dua hari tersebut. Menurut guru kegiatan ini sangat bermanfaat karena dapat memberikan inspirasi kepada guru sehingga dapat memberikan kesan bahwa matematika menyenangkan bagi siswa. Adapun saran yang disampaikan oleh guru terkait kegiatan ini adalah lebih sering diadakan kegiatan sejenis agar dapat menambah khasanah pengetahuan bagi guru. Luaran yang didapat dari pengabdian ini, yaitu guru-guru Ml seJagakarsa dapat menerapkan pengetahuan yang didapat dari kegiatan pengabdian ini kepada siswa,

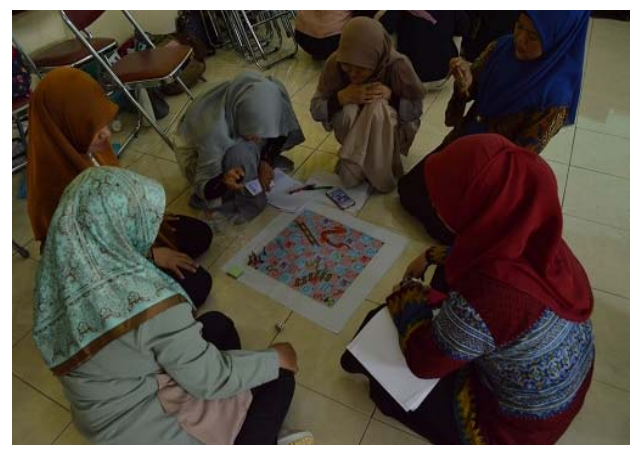

Gambar 1. Guru Melakukan Simulasi Permainan Ular Tangga

Ular tangga adalah salah satu permainan tradisional yang biasa dimainkan oleh dua orang atau lebih, setiap pemain diberikan pion atau bidak dan setiap giliran melemparkn dadu. Pion atau bidak mewakili pemain akan dijalankan sesuai dengan jumlah dadu yang keluar. Papan permainan ular tangga terdiri dari kotak-kotak kecil yang sudah diberi nomor dan beberapa gambar seperti tangga dan ular, yang dapat menghubungkan kotak satu ke kotak yang lainnya. Jika pion atau bidak mendarat di ujung tangga, maka pemain dapat menjalankan pionnya naik ke ujung tangga yang lain. Jika pion pemain mendarat pada kotak dengan gambar ular, maka pion pemain tersebut harus turun ke kotak di ujung ular yang lain. Inovasi yang diberikan di permainan ini adalah pada beberapa kotak tertulis "DARE" dan berisi kartu soal yang harus diikuti instruksinya oleh pemain. Adapun langkah-langkah permainan ular tangga pada kegiatan ini, adalah

a. Siswa dibagi menjadi beberapa kelompok, dan tiap kelompok terdiri dari $5-6$ orang.

b. Urutan pemain dapat ditentukan dengan hompimpa atau dengan mengocok dadu.

c. Pilih tiap pion dan mulailah dari start.

d. Kocok dadu oleh setiap pemain, dan melangkah sesuai jumlah mata dadu yang keluar.

e. Jika pion berhenti di gambar ular, maka pion harus turun sesuai alur dari ular.

f. Jika pion berhenti di gambar tangga, maka pion naik sesuai alur dari tangga.

g. Jika pion berhenti di tulisan "DARE!!!" maka pemain wajib mengambil kartu tantangan yang dikocok terlebih dahulu, dan melakukan instruksi sesuai dengan yang tertera pada katu tersebut.

h. Jika mata dadu yang keluar adalah angka 6, maka pemain boleh mengocok dadu lagi, dan melangkah sesuai total jumlahnya.

i. Pemain yang sampai ke garis finish (gambar piala) dinyatakan sebagai pemenang.

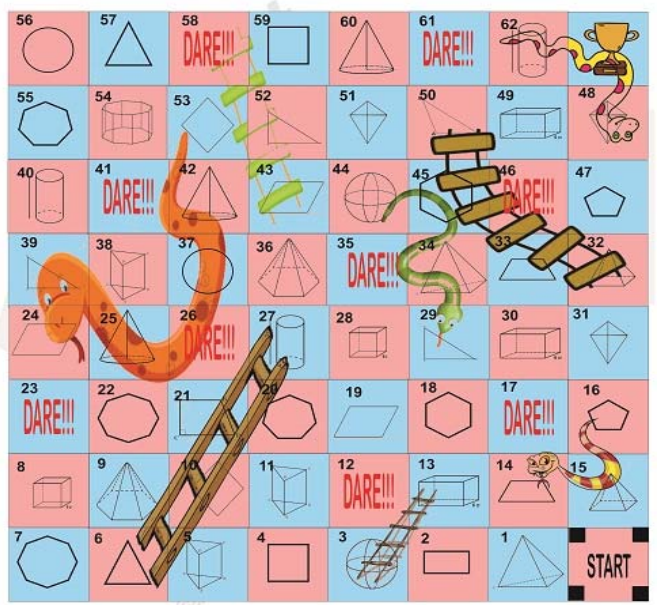

Gambar 2. Papan Permainan Ular Tangga 
Gambar 2. menunjukkan papan permainan ular tangga yang telah diintegrasikan dengan konsep-konsep yang ada dalam matematika. Pada papan permainan ular tangga, terdapat gambar-gambar bangun yang dapat diidentifikasi oleh siswa. Guru dapat mengembangkan sendiri soal-soal apa yang akan diberikan kepada siswa sebagai bahan permainan sesuai dengan tema yang diajarkan. Pada kegiatan ini, tim menyiapkan kartu soal mengenai materi bangun datar, bangun ruang, perkalian, pembagian, dan aplikasinya dalam kehidupan sehari-hari. Contoh kartu soal yang tim siapkan seperti berikut:

a. Mundur sebanyak $32: 8$.

b. Maju sebanyak $3 \times 2$,

c. Berapa hasil perkalian dari 13 × 3 jika benar maju 2 langkah.

d. Berapa hasil pembagian dari $196:$ 14, jika gagal mundur 1 langkah.

e. Andi membeli 5 buku seharga Rp. 12.500, berapa harga tiap satu buku? Jika berhasil maju 1 langkah.

f. Tebak bangun dua langkah di depan, jika berhasil maju 2 langkah.

g. Sebuah taman akan dipagari dengan 12 batang kayu. Jika panjang taman $60 \mathrm{~cm}$, berapa jarak tiap batang? Jika gagal mundur 2 langkah.

Kegiatan pengabdian ini dinilai mampu menumbuhkan sikap positif siswa terhadap pembelajaran matematika, serta mengubah cara pandang siswa yang menganggap matematika pelajaran membosankan serta menakutkan. Melalui permainan, siswa mampu mengeksplorasikan sesuatu hal baru dan belajar dengan cara yang menyenangkan. Menurut Nurrahmah \& Ningsih (2018) pada dasarnya, belajar melalui pendekatan permainan yang kreatif memiliki tujuan yang utama yaitu mengoptimalkan perkembangan anak usia dini dan anak-anak. Permainan ular tangga dapat mengoptimalkan proses pembelajaran matematika di kelas, karena seluruh siswa akan terlibat aktif dalam belajar. Siswa tidak akan merasa bosan karena ktivitas belajarnya dikemas dalam alat permainan. Seperti pendapat [5] yang menyatakan bahwa pembelajaran matematika dengan permainan ular tangga dapat memotivasi siswa untuk terus belajar mengembangkan kemampuannya dengan melibatkan siswa secara aktif dalam pembelajaran. Masih menurut [5], melalui permainan, maka terjadi rangsanganrangsangan yang membuat siswa memahami konsep dan pengetahuan secara alamiah serta membantu anak untuk mengembangkan kecerdasannya, sehingga dapat meningkatkan pemahaman konsep dan hasil belajarnya.

Lebih lanjut lagi, permainan ular tangga ini hanya salah satu dari sekian banyak permainan yang dapat diterapakan dalam pembelajaran. Kondisi Indonesia dengan berbagai hasil budaya, khususnya permainan, dapat digali lagi sebagai pendekatan dalam pembelajaran matematika. Mengacu penelitian Risdiyanti \& Prahmana (2018), sehingga nantinya integrasi yang melibatkan budaya dan matematika yang diajarkan di sekolah seharusnya fakta, konsep, dan konten dapat diterima secara universal

\section{SIMPULAN DAN SARAN}

Pembelajaran matematika melalui permainan dapat digunakan oleh guru dalam melaksanakan tugasnya untuk menyampaikan materi dan membantu pembentukan sikap siswa. Kegiatan pengabdian ini diharapkan mampu menumbuhkan sikap positif kepada siswa dalam pembelajaran dan dapat mengubah cara pandang siswa terhadap mata pelajaran matematika. Salah satu permainan yang dapat dijadikan media untuk melibatkan siswa secara aktif dalam pembelajaran adalah ular tangga. Permainan ular tangga dipilih karena dalam permainan ini dapat dikaitkan dengan bermacam-macam materi pelajaran matematika sehingga guru dapat mengkreasikan sendiri permainan ini. Guru dibantu untuk dapat merancang pembelajaran yang lebih menyenangkan bagi siswa. Jika pada permainan ular tangga biasa hanya menggunakan papan ular tangga, pion, dan dadu, pada permainan ini disiapkan kartu isntruksi berisi soal-soal yang harus dijawab dan diikuti oleh siswa. Kartu ini berisi tentang materi pembelajaran yang dapat diomodifikasi pertanyaannya oleh guru sesuai dengan bahasan yang diajarkan. Dengan adanya inovasi pembelajaran matematika melalui permainan ular tangga, dapat menjadikan matematika sebagai pelajaran yang menyenangkan dan asyik dipelajari oleh siswa. Hasil dari pengabdian masyarakat ini dapat dilanjutkan dengan pengembangan ataupun pemodifikasian terhadap permainan ular tangga. Dengan menambahkan konsepkonsep matematika yang lain. Pengabdian masyarakat ini juga dapat ditindaklanjuti dengan penelitian, meneliti keefektifan penggunaan permainan ular tangga dalam proses pembelajaran matematika.

\section{UCAPAN TERIMA KASIH}

Apresiasi dan terima kasih kepada Direktorat Riset dan Pengabdian Masyarakat, Direktorat Jenderal Penguatan Riset dan 
Pengembangan, Kementerian Riset, Teknologi dan Pendidikan Tinggi yang telah membiayai kegiatan Pengabdian kepada Masyarakat melalui Program Kemitraan Masyarakat Tahun 2019 dengan judul "Inovasi Pembelajaran Matematika SD/MI yang Menyenangkan Melalui Pendekatan Permainan Tradisional". Terima kasih juga kepada LLDIKTI Wilayah III Jakarta dan Lembaga Penelitian dan Pengabdian Masyarakat Universitas Indraprasta PGRI yang telah membantu Kegiatan Pengabdian kepada Masyarakat ini melalui Kontrak Program Pengabdian kepada Masyarakat: Nomor: 17/AKM/P2M/2019, tanggal 27 Maret 2019. Dan surat Perjanjian/Kontrak Pengabdian kepada Masyarakat UNINDRA Nomor: 0411/SKP2M/LPPM/UNINDRA/III/2019 tanggal 27 Maret 2019.

\section{DAFTAR RUJUKAN}

Ferryka, P. Z. (2017). Permainan Ular Tangga Dalam Pembelajaran. Magistra, 29(100), 58-65. Retrieved from http://journal.unwidha.ac.id/index.php/MA GISTRA/article/view/872

Mulyatna, F. (2017). Analysis Lesson Plan Mathematics by Curriculum 2013 Implementation Using Inquiry Method. 993-1001. Proceedings International Conference on Education and Science (ICONS 2017).

Mulyatna, F., Indrawati, F., \& Hartati, L. (2018). PELATIHAN PEMBUATAN RENCANA PELAKSANAAN PEMBELAJARAN BERDASARKAN KURIKULUM 2013 DI YAYASAN RAUDLATUL JANNAH. Abdimas Dewantara, 1(1), 11-22. Retrieved from http://jurnal.ustjogja.ac.id/index.php/abdi masdewantara/article/viewFile/2128/1460

Nurrahmah, A., \& Ningsih, R. (2018). Penerapan Permainan Tradisional Berbasis Matematika. Wikrama Parahita: Jurnal Pengabdian Masyarakat, 2(2), 43. https://doi.org/10.30656/jpmwp.v2i2.631

Risdiyanti, I., \& Prahmana, R. C. I. (2018). Ethnomathematics: Exploration in Javanese culture. Journal of Physics: Conference Series, 943(1). https://doi.org/10.1088/17426596/943/1/012032

Turmudi. (2008). Landasan Filsafat dan Teori Pembelajaran Matematika. Jakarta: PT. Leuser Cita Pustaka. 